\title{
The Logic of Divine Love
}

\section{A Critical Analysis of the Soteriology of Peter Abailard RICHARD E. WEINGART}

This book introduces the dialectical theology of Abailard himself and presents the most important results of Abailardian studies and researches. The topics covered include the controversy on atonement, the theory on the formation of the doctrine of the sacraments, the problem of relationship between raison and faith, God and man, grace and responsibility. $£ 2.50$

\section{God and Rationality}

\section{THOMAS F. TORRANCE}

This is a sequel to Professor Torrance's Theological Science and to his Space, Time, and Incarnation. He calls for a 'return to theological rationality'; theological thinking must not be a construction of man's making but controlled and conditioned by the nature of its Object, God the supreme reality. $£ 2.75$

\section{New Liturgical Feasts in Later Medieval England}

\section{R. W. PFAFF}

This work is a study of a number of feasts which came, or were in the process of coming, into English service-books during the century or so before the Reformation, among them the Transfiguration, Visitation, and Holy Name. The service forms used for these feasts, and the currents of spirituality, patronage, or ecclesiastical politics which promoted them, are traced primarily with respect to late medieval England. $£ 1.75$

Oxford Theological Monographs

\section{Christian Faith and Other Faiths}

The Christian Dialogue with other Religions

\section{STEPHEN NEILL}

In this assessment of non-Christian religions from a Christian standpoint, Bishop Neill discusses the faith of contemporary primitive people as well as the main established religions, and modern forms of secularism including existentialism. The 1961 hardcover edition has been revised throughout and new material added for this second edition in Oxford Paperbacks. 75p

\section{OXFORD UNIVERSITY PRESS}




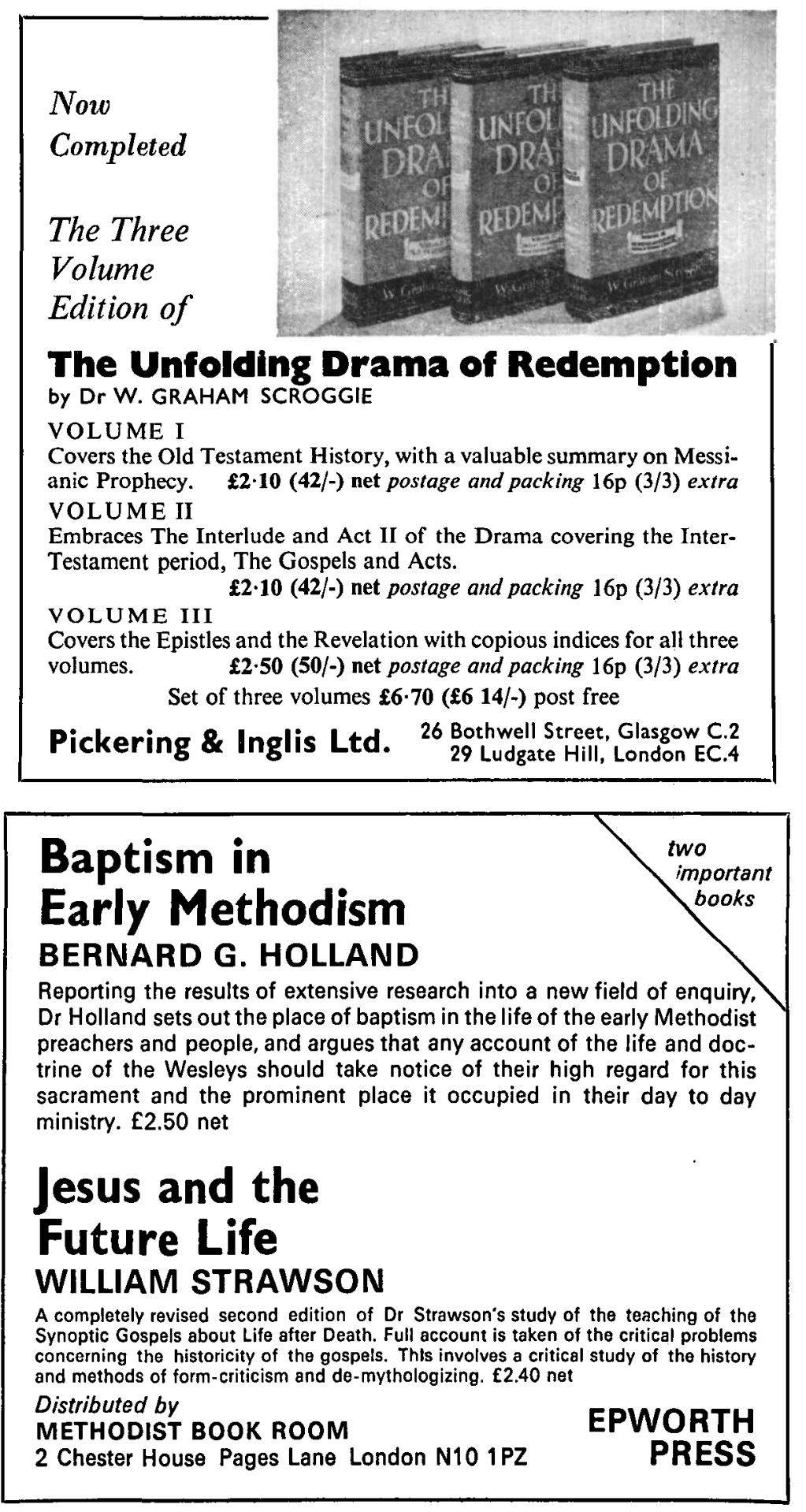




\section{NOTES FOR CONTRIBUTORS}

Contributions and editorial correspondence should be sent to one of the editors: Rev. Professor T. F. Torrance, 37 Braid Farm Road, Edinburgh, eн io 6le, Scotland; Rev. Professor J. K. S. Reid, Don House, 46 Don Street, Aberdeen, AB2 IUU, Scotland.

Submission of an article is taken to imply that it has not previously been published in English, or is not being considered by another journal for publication in English. The average length of articles is 5000 words. Although longer articles are accepted, those in excess of 10,000 words cannot be considered.

Contributions (articles and reviews) should be clearly typed in double spacing, and on one side of the paper only. The rule about double spacing applies also to footnotes, which should be used sparingly. Cross-references within the article offered should not be included.

Notes for the editors and instructions for the printer should be attached on separate sheets. Contributors should keep one copy of the typescript for use in correcting proofs.

Contributors from the United States may use U.S. spellings. Greek and Hebrew words need not be transliterated. Capitalisation should be kept to a minimum; and in particular should not be used in pronouns referring to the Deity.

First proofs of articles and article reviews may be read and corrected by contributors, and should normally be returned to the organising editor within ten days of receipt. Correction should be confined to errors of the printer. More extensive correction can be made only with the concurrence of an editor. No proofs of reviews will be sent.

Contributors of articles and article reviews (but not of reviews) receive 25 free offprints. Extra copies may be bought according to an agreed scale of charges, provided that these are ordered at the time of returning corrected proofs. 


\section{CONTENTS}

Revelation and religion in the theology of Karl Barth, by J. A. VeIтch (Makassar, Indonesia)

Natural theology and the Scottish philosophy in the thought of Thomas Chalmers, by Daniel F. Rice (Boone, $\mathcal{N}$. Carolina)

The fundamental shape of Old Testament ethics, by Verne H. Fletcher (Beirut)

The body of Christ and related concepts in I Corinthians, by A. J. M. Wedderburn (Cambridge)

\section{REVIEWS}

RICHMond: Theology and Metaphysics

RAHNER: The Trinity

LEWIS: Our Experience of God

GARAUDY: Marxism in the

Twentieth Century

MACQUARRIE: Three Issues in Ethics

KING: A Christian View of the Mushroom Myth

SANDMEL: Old Testament Issues

ENGNELL: Critical Essays on the Old Testament

ELLis (ed.): The Gospel of Luke METZGER: The Text of the New Testament

MARXSEN: The Resurrection of Jesus of Nazareth. Evans: Resurrection and the New Testament
FINEGAN: The Archaeology of the New Testament

SEAVER: The Puritan Lectureships.

BUCHANan et al.: Growing into Union

heidemann: Reformed Bishops \& Catholic Elders

118

HAHN et al.: What can we know about Jesus? BARCLAY: The King and the Kingdom. MARTIN: Suffering Man, Loving God. E. BONHOEFPER:

I06 Auschwitz Trials. STEWART:

107 The Lower Levels of Prayer. Protestant-Catholic Marriages. HEGGEN : Children and Confession

Godfrey: The English Parish, 600-1 300

II BOOKS RECEIVED 